Хірургічна стоматологія

УдК 616.716.1-0015:612.311:616-07

DOI 10.11603/2311-9624.2021.3.12460

(ㄷ. В. Шуминський ${ }^{1}$, А. В. Копчак ${ }^{1}$ В. Г. Гурьянов ${ }^{1}$, Н. В. Лисейко ${ }^{1}$, О. М. Дорошенко ${ }^{2}$

Національний медичний університет імені О. О. Богомольця, м. Київ ${ }^{1}$

Національний університет охорони здоров'я України імені П. Л. Шупика, м. Київ ${ }^{2}$

E-mail: shuminsky@icloud.com

\title{
Оцінка оклюзійних співвідношень та жувальної функції у пацієнтів із переломами верхньої щелепи методом комп'ютерної оклюзіографіï
}

\section{ІНФОРМАЦІЯ}

Надійшла до редакції/Received: 16.07.2021 p.

Ключові слова: Le Fort; переломи верхньої щелепи; Tscan; оклюзіографія; контрфорс.

\section{АНОТАЦІЯ}

Резюме. Уламкові переломи верхньої щелепи на ділянці вертикальних контрфорсів ускладнюють процес репозиції та фіксації, створюють передумови для розвитку глибоких функціональних розладів у ранньому і віддаленому посттравматичному періодах. Відновлення їх за допомогою накісних титанових пластин є основним завданням лікування даної категорії пацієнтів.

Мета дослідження - дослідити характер оклюзійних співвідношень та визначити їх зміни у пацієнтів із травматичними переломами верхньої щелепи залежно від застосованого способу реконструкції вертикальних контрфорсів із використанням методу комп’ютерної оклюзіографії.

Матеріали і методи. Досліджено 18 пацієнтів із множинними переломами кісток середньої зони обличчя (15 чоловіків та 3 жінок). Середній вік $(43,8 \pm 10,8)$ року. Оклюзіографії проводили у групах із лінійними переломами (Gr1, n=6), з кістковими дефектами у ділянці вертикальних контрфорсів (Gr2, n=5) та з відновленими контрфорсами за допомогою кісткових аутотрансплантатів (Gr3, n=7). Аналіз проведений за допомогою апарату та програмного забезпечення «T-Scan» компанії «Tekscan» (Tekscan, Inc., S. Boston, MA, США). Досліджені час оклюзії, дезоклюзії, індекс асиметрії оклюзії. Результати досліджень та їх обговорення. Медіанні значення часу оклюзії, дезоклюзії, індексу асиметрії Gr1- $(0,17(0,12 \div 0,25), 0,18$ $(0,15 \div 0,19), 12,2 \%(8 \% \div 29,1 \%))$; Gr2 - $(0,29(0,18 \div 0,37), 0,13(0,12 \div 0,20)$, $28,4 \%(16,8 \div 36,8) \%)$; Gr3 - (0,22 (0,21 $\div 0,38), 0,11(0,08 \div 0,22), 23,2 \%$ $(15,4 \div 29,7) \%)$ відповідно. Визначалась тенденція до зростання часу оклюзіїна $24 \%$, часудезоклюзії-на $16 \%$ та ступеня асиметрії-на $17 \%$ у пацієнтів із переломами нижньої щелепи, що супроводжувались відшаруванням або пересіченням жувальних м’язів та у пацієнтів, яким проводили біфронтальний доступ, що супроводжувалось оголенням скроневих м’язів для лікування переломів кісток середньої зони обличчя.

Висновки. Чинниками, що сприяють поглибленню функціональних змін, є переломи верхньої щелепи із дефектом (зростання індексу асиметрії в середньому на 13,6 \% та часу оклюзії - на 0,1 c), а також операційна травма жувальних м'язів при проведенні хірургічних доступів. Заміщення дефектів вертикальних контрфорсів кістковими аутотрансплантатами покращує відновлення жувальної функції, порівняно із пацієнтами, де для фіксації уламків на ділянці дефектів використовували накісні міні-пластини як самостійне хірургічне рішення (середній час оклюзії у цієї категорії хворих був меншим на 25 \%, а індекс асиметрії - на 19 \%). 
Вступ. Єдність зубощелепної системи забезпечується тісною взаємодією зубних рядів, щелеп, жувальної і мімічної мускулатури та скроневонижньощелепних суглобів (СНщС) [1, 2]. При травматичних переломах кісток обличчя порушується опорна здатність структур, що сприймають і перерозподіляють жувальне навантаження. Це створює передумови для розвитку глибоких функціональних розладів як в ранньому, так і у віддаленому посттравматичному періодах. Основним завданням хірургічного лікування кісток обличчя є відновлення їх цілості й правильних топографо-анатомічних співвідношень, та досягнення максимально повного відновлення естетики і функції щелепно-лицевої ділянки. Відомо, що у пацієнтів із переломами щелеп у 3,7-8,5 \% випадків розвиваються посттравматичні порушення прикусу, в $(9,8 \pm 21) \%$ виникають контрактури нижньої щелепи (Нщ) із обмеженням як відкриття рота, так і протрузійних або латеротрузійних рухів [3-5]. Доведено, що при переломах нижньої щелепи 100 \% випадків у віддаленому післяопераційному періоді відзначають ознаки м'язовосуглобової дисфункції та структурно-функціональні порушення в СНЩс, які виникають не лише при переломах їі виросткового відростка, але й при переломах кута і тіла [6]. Щодо переломів верхньої щелепи, то для пацієнтів цієї категорії віддаленні функціональні наслідки, і питання відновлення оклюзії і жувальних рухів є менш дослідженими. Однак у роботі Zachariades et al. (1993) зазначалось, що порушення оклюзії після хірургічного лікування переломів верхньої щелепи становлять 2-8 \% [7]. На необхідності й складності відновлення оклюзії при даному виді травми в своїх роботах наголошували Manson et al. (1986); Zachariades et al. (1993); Kühnel et al. (2015) [7-9]. Повноцінний, множинний міжзубний контакт дозволяє не лише ретельно пережовувати та подрібнювати їжу, що упереджує захворювання зі сторони шлунково-кишкового тракту, а також дозволяє уникнути ряду інших важливих ускладнень $з$ боку зубощелепної системи і зокрема СНщС, але його відновлення при травмі лицевого черепа в багатьох випадках становить не просте завдання.

Як відомо з літературних джерел, однією із основних функцій верхньої щелепи є створення опори для верхнього зубного ряду, визначення позиції альвеолярного відростка в просторі, захисна, сприйняття і розподіл жувального навантаження, що забезпечується через систему вертикальних та горизонтальних контрфорсів [10]. Переломи верхньої щелепи та кісток середньої зони обличчя можуть супроводжуватися уламковою фрагментацією та/або формуванням кісткових дефектів на ділянках цих контрфорсів. Останні суттєво погіршують біомеханічні умови для протидії жувальному навантаженню та ускладнюють фіксацію фрагментів верхньої щелепи в правильному положенні [11]. «Золотим стандартом» лікування перелому верхньої щелепи (ПВЩ), згідно рекомендацій АО CMF, на сьогодні є відновлення цілості вертикальних контрфорсів (носолобових та вилице-верхньощелепних) за допомогою накісних титанових пластин $[12,13]$. Цей підхід забезпечує стабільне утримання альвеолярного відростка верхньої щелепи в правильному положенні відносно вищерозташованих кісткових структур і нижнього зубного ряду. Втім у випадку багатоуламкової фрагментації чи утворення дефектів на ділянці носо-лобового чи вилице-верхньощелепного контрфорсів, стабільність фіксації знижується. Дослідники зазначають, що переломи верхньої щелепи є одними з найбільш складних видів переломів кісток обличчя. Особливістю даного виду травми є значна індивідуальна варіативність характеру перелому, його топографічних характеристик і клінічних проявів. На даний час переломи верхньої щелепи за класичною схемою Rene Le Fort зустрічаються вкрай рідко і часто поєднуються з переломами інших зон обличчя [14]. При високоенергетичній травмі хірург часто зустрічається із дрібноуламковою фрагментацією, втратою життєздатності кісткових фрагментів, i, як наслідок, утворення дефектів значної протяжності.

В таких умовах титанові пластини самі по собі не здатні сприймати жувальне навантаження в повному обсязі без незворотної деформації, та забезпечити його природний розподіл у кістковій тканині. Для титанових конструкцій притаманний ефект екранування напружень та виникнення ділянок їх локальної концентрації навколо фіксуючих гвинтів, що при тривалому циклічному навантаженні призводить до резорбції кістки і втрати елементів фіксації. У роботі Шуминського та ін. (2020) було показано, що у випадку формування дефекту вилице-верхньощелепного контрфорсу напруження, що виникали в моделях, у середньому їх величина становила $(59,8 \pm 34,7)$ МПа, а в окремих спостереженнях вони перевищували 100 МПа, що створювало ризик пластичної деформації та руйнування фіксаторів від втоми. За наявності дефектів на ділянцівертикальних контрфорсів верхньої щелепи, інтегральна жорсткість фіксації накісними пластинами зменшується в 2,6 раза, а напруження в елементах фікса- 
ції над ділянкою дефекту зростають в середньому на $46 \%$. Заміщення дефектів вертикальних контрфорсів верхньої щелепи кістковими аутотрансплантатами при проведенні остеосинтезу дозволяє збільшити інтегральну жорсткість фіксації у середньому в 2 рази та зменшити еквівалентні напруження за Мізесом в елементах фіксації в середньому на 30 \% [11].

Як свідчать проведені дослідження з біомеханічної точки зору, найкращі результати досягаються при точному зіставленні всіх кісткових уламків і реалізації load-sharing-ефекту - перерозподілу функціональних навантажень між кісткою та фіксатором, що суттєво розвантажує останній та забезпечує розподіл напружень, близький до природного [15]. За наявності дефектів вертикальних контрфорсів перерозподіл навантаження між фіксатором і кісткою можливий у разі застосування кісткових аутотрансплантатів із верхньої щелепи, підборіддя, зовнішньої косої лінії нижньої щелепи та склепіння черепа. Використання кісткових аутотрансплантатів у цих випадках направлено не лише на покращення біомеханічних умов у зоні проведення остеосинтезу, але й сприяє оптимізації репаративних процесів, знижує ризик вторинних зміщень, дисбалансу оклюзійних співвідношень тощо [11].

Переваги застосування кісткових аутотрансплантатів були показані в ряді експериментальних досліджень і окремих клінічних серіях. Водночас у доступній нам літературі відсутні роботи, присвячені вивченню жувальної функції та особливостям відновлення оклюзійних співвідношень у пацієнтів, прооперованих із використанням даної техніки.

Метою дослідження було дослідити характер оклюзійних співвідношень та визначити їх зміни у пацієнтів із травматичними переломами верхньої щелепи залежно від застосованого способу реконструкції вертикальних контрфорсів верхньої щелепи із використанням методу комп’ютерної оклюзіографії.

Матеріали і методи. Загальна характеристика клінічного матеріалу, критерії включення $i$ виключення. Матеріалом дослідження були 18 пацієнтів із множинними травматичними переломами кісток середньої зони обличчя (15 чоловіків та 3 жінок) віком від 25 років до 62 років (в середньому $(43,8 \pm 10,8)$ року, що перебували на стаціонарному лікуванні у відділеннях нейрохірургії та політравми Київської міської клінічної лікарні швидкої медичної допомоги. Критеріями включення в дослідження були - наявність у па- цієнта із переломами кісток лицевого черепа, що найменше одного із типів перелому верхньої щелепи за Rene Le Fort (I, II чи III) із руйнуванням вертикальних контрфорсів ВЩ (вилице-верхньощелепний та носо-лобовий), хірургічне лікування перелому із використанням відкритої репозиції та остеосинтезу, письмова згода на участь в дослідженні, повне клініко-рентгенологічне документування випадку. Критеріями виключення були пацієнти з вогнепальними переломами кісток лицевого черепа, вік пацієнтів до 18 років, наявність дефектів зубних рядів або неякісних протезних конструкцій, наявність глибоких психо-неврологічних розладів внаслідок перенесеної черепно-мозкової травми, не дотримання лікарських рекомендацій, неточна репозиція верхньої щелепи за даними контрольних КТ, розвиток ускладнень в післяопераційному періоді, відсутність ефективної взаємодії з лікарем, відмова пацієнта від участі в дослідженні.

Усіх пацієнтів у групах спостереження обстежили згідно зі стандартною схемою, що включала збір анамнезу, оцінку загального та місцевого статусу із обчисленням індексу тяжкості лицевої травми Facial Injury Severity Scale (FISS) [17].

Залежно від способу фіксації уламків верхньої щелепи на ділянці вертикальних контрфорсів верхньої щелепи пацієнтів поділили на три групи. До першої групи (Gr1, n=6) віднесли пацієнтів, у яких відновлення вилице-верхньощелепних та носо-лобових контрфорсів відбувалося із використанням титанових міні-пластин за умови анатомічно правильного зіставлення усіх уламків. До другої групи (Gr2, n=5) належали пацієнти, в яких у результаті уламкової фрагментації формувалися дефекти вертикальних контрфорсів, а відновлення їх анатомічної неперервності проводили із використанням пластин підвищеної жорсткості. До третьої групи (Gr3, n=7) віднесли хворих, у яких відновлення вилице-верхньощелепного та/або носо-лобового контрфорсу відбувалося шляхом використання титанових накісних міні-пластин у поєднанні з кістковими аутотрансплантатами з передньої стінки верхньощелепного синуса, підборіддя або зовнішньої косої лінії нижньої щелепи (рис. 1).

У ранньому післяопераційному періоді в пацієнтів застосовували раннє функціональне навантаження. За наявності переломів нижньої щелепи, що супроводжувалось відшаруванням або пересіченням жувального м'яза, проведенням коронального доступу, із пересіченням і відшаруванням скроневого м’яза, використовували направляючі еластичні тяги, що дозволяли зіста- 


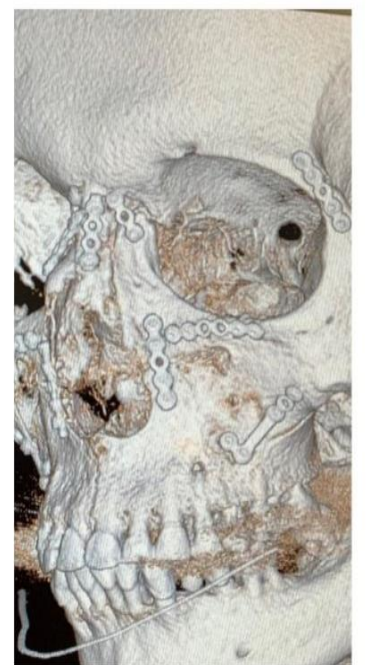

Gr1

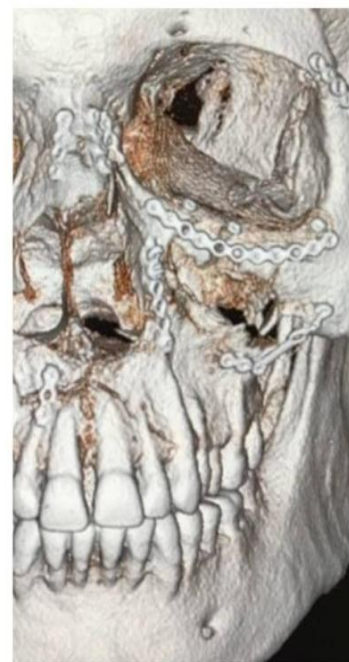

Gr2

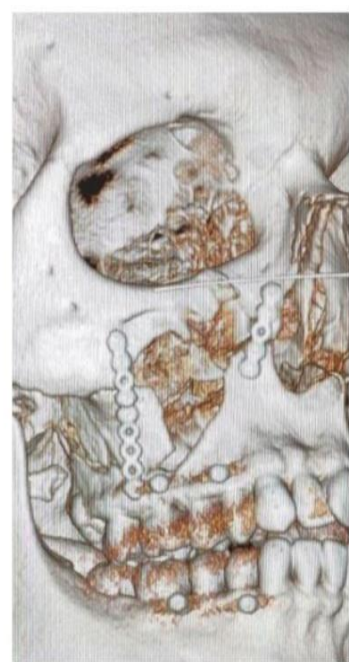

Gr3

Puc. 1. 3D-реконструкція кісток лицевого скелета пацієнтів у групах дослідження залежно від способу фіксації уламків.

вити зубні ряди у стані множинного контакту та визначали правильне взаємне співвідношення щелеп у ранньому післяопераційному періоді. Протягом 6 тижнів після операції хворі отримували м’яку дієту та мали уникати значних фізичних навантажень. Усім пацієнтам надавались рекомендації щодо дотримання гігієни порожнини рота.

Усім обстеженим проводили КТ: перед хірургічним втручанням, у перші 3 дні після операції, та через 1,5 місяця (для контролю стабільності результату втручання та наявності післяопераційних ускладнень). Для визначення архітектоніки та особливостей будови кісток середньої зони обличчя в пацієнтів у групах дослідження визначали індекс пневматизації (IП) як співвідношення між об’ємом кісткової тканини та об’ємом повітроносних порожнин середньої зони обличчя [16].

Аналіз оклюзійних співвідношень. Аналіз оклюзійних співвідношень проводили методом комп’ютерної оклюзіометрії за допомогою апарату та програмного забезпечення «T-Scan» компанiï «Tekscan» (Tekscan, Inc., S. Boston, MA, США), що дозволяє збирати, систематизувати й аналізувати дані про послідовність контактів у режимі реального часу, час виникнення першого контакту та його локалізацію, зміну оклюзійних співвідношень зубних рядів від першого контакту до максимального міжгорбкового контакту, а також визначати силу стискання зубних рядів протягом певного проміжку часу. В основі методу лежить передача електричного сигналу від ультратонкого гнучкого датчика, що визначає силу стискання зубів. Кожний датчик має у своєму складі чутливі елементи «Сенсели», що утворюють лінії та стовпчики на датчику. На екрані кожний сенсел виглядає як окремий квадрат. Пацієнт стискає зубні ряди до максимального фісурно-горбкового контакту, прикушуючи при цьому сенсор, який приєднаний до комп’ютера. Програмне забезпечення аналізує місце розміщення контактів, їх силу і послідовність протягом відрізку часу. Оклюзійні сили представленні у вигляді кольорової шкали, від синього (самий слабкий контакт) до рожевого (самий сильний контакт). Після проведення у кожного пацієнта декількох послідовних записів різних видів оклюзії зубних рядів можливе подальше ï аналізування у двовимірному та тривимірному зображенні.

Дослідження оклюзійних співвідношень проводили у всіх хворих відповідно до стандартного протоколу в строки від 4 до 6 місяців після хірургічного лікування. Дослідження проводили на базі стоматологічного медичного центру Національного медичного університету імені О. О. Богомольця у період з 2016 до 2021 року. При аналізі отриманих даних враховували наступні характеристики оклюзії:

- час оклюзії та дезоклюзії, фіксація перших контактів, супраконтактів, вектор сумарного оклюзійного навантаження, баланс оклюзії у момент максимального міжгорбкового змикання у стані центральної оклюзї;

- контакти та супраконтакти у стані протрузіі, лівій та правій латеротрузії та за умов контактів у центральному співвідношенні.

Різницю між показниками балансу оклюзії правої та лівої сторони вираховували як індекс асиметрії [18].

ISSN 2311-9624. Клінічна стоматологія. 2021. № 3 


\section{Хірургічна стоматологія}

При проведенні статистичного аналізу характер розподілу кількісних показників у групах визначали за критерієм Шапіро - Уїлка. Для представлення даних у випадку нормального закону розподілу визначали середнє значення (M) та стандартне відхилення ( $\pm \mathrm{SD})$, у випадку розподілу показників за законом відмінним від нормального визначали медіанні значення (Ме) та міжквартильний інтервал (QI-QIII). Визначення розбіжностей за цими параметрами в групах порівняння проводилось за критерієм ANOVA або за критерієм Краскала - Уолліса. Для визначення наявності зв’язку між показниками розраховували показник рангової кореляції Спірмена. Для якісних ознак розраховувалася частота їх прояву (\%). Порівняння якісних ознак проводилося за точним критерієм Фішера. Аналіз проводили 3 використанням статистичного пакета EZR v.1.54 (graphical user interface for $\mathrm{R}$ statistical software version 4.0.3, R Foundation for Statistical Computing, Vienna, Austria) [19].

Результати досліджень та їх обговорення. При аналізі передопераційних КТ було встановлено, що тяжкість травми та особливості архітектоніки кісток середньої зони обличчя (ступінь їх пневматизації) у клінічних групах вірогідно не відрізнялись. Значення IП, даних тяжкості щелепно-лицевої травми за FISS, та статистичної вірогідності між групових розбіжностей за критерієм Тьюкі наведені у таблиці 1 та на рисунках 2, 3.

На момент обстеження всі пацієнти вказували, що в результаті хірургічного втручання повноцінне змикання зубів було відновлено, скарг на утруднене пережовування їжі, дискомфорт у зоні переломів та СНЩС не було. Втім при проведенні комп’ютерної оклюзіографії наявність супраконтактів та контактів надмірної сили при різних варіантах оклюзї визначали в усіх 100 \% обстежених

таблищя. 1. Значення індексу пневматизації та тяжкості щелепно-лицевої травми у групах порівняння

\begin{tabular}{|l|c|c|c|c|}
\hline Досліджуваний показник & $\begin{array}{c}\text { Gr1 } \\
(\mathrm{n}=6)\end{array}$ & $\begin{array}{c}\mathrm{Gr} 2 \\
(\mathrm{n}=5)\end{array}$ & $\begin{array}{c}\mathrm{Gr} 3 \\
(\mathrm{n}=7)\end{array}$ & $\begin{array}{c}\text { Рівень значущості відмінності } \\
\text { показників між групами, } \\
\mathrm{p}\end{array}$ \\
\hline $\begin{array}{l}\mathrm{I \Pi} \\
\mathrm{M} \pm \mathrm{SD}\end{array}$ & $1,18 \pm 0,27$ & $0,94 \pm 0,09$ & $1,04 \pm 0,18$ & 0,213 \\
\hline $\begin{array}{l}\text { FISS } \\
\mathrm{M} \pm \mathrm{SD}\end{array}$ & $7 \pm 4,5$ & $7,2 \pm 4,9$ & $4,2 \pm 1,8$ & 0,29 \\
\hline
\end{tabular}

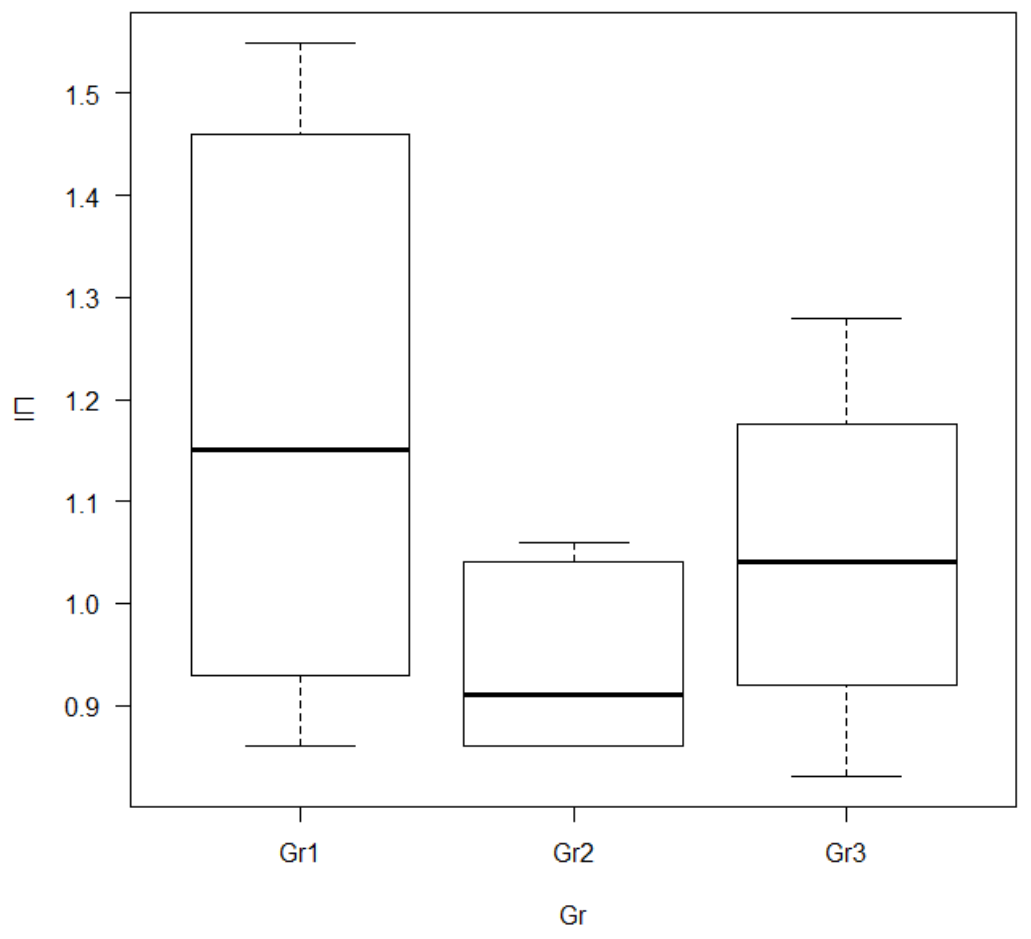

Puc. 2. Значення індексу пневматизації у групах дослідження. Порівняння показника проведено за критерієм ANOVA. Попарні порівняння проведені за критерієм Тьюкі. 


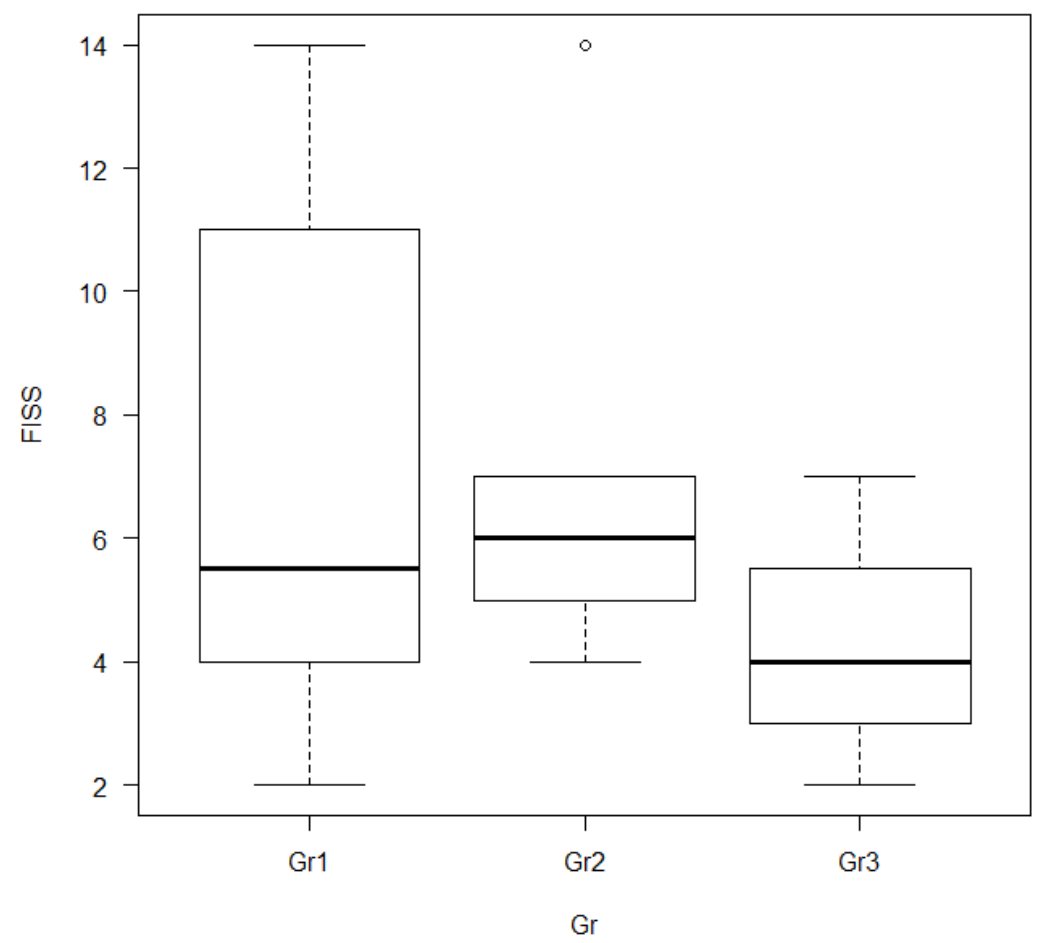

Puc. 3. Значення показника Facial Injury Severity Scale у групах дослідження. Порівняння проведено за критерієм ANOVA. Попарні порівняння проведені за критерієм Тьюкі.

хворих. Відзначено, що зазвичай перші контакти і супраконтакти відзначалися у зоні молярів верхньої щелепи. У 67 \% при змиканні зубів у центральній оклюзії супраконтакти виникали на молярах з одного боку, з наступним приєднанням супраконтактів на молярах протилежного боку із поступовим зростанням площі контакту і формуванням множинного фігурно-горбикового змикання. В окремих випадках визначали супраконтакти на різцях іклів-премолярів.

Показники балансу оклюзії між правою і лівою стороною коливалися від 51-49 \% до 85,4-
14,6 \%; показник асиметрії оклюзії знаходився у межах від 2 до 70,8 \% (табл. 2, рис. 4-7).

У ситуаціях, коли у пацієнта з одного боку був наявний перелом із дефектом, заміщений пластиною, а з іншого боку, - перелом, фіксований без дефекту кістки, перші контакти завжди виникали на боці, де дефект контрфорсів був відсутній. При цьому бік першого контакту між зубами збігався з вектором сумарного оклюзійного навантаження у 77,8 \% випадків.

Час оклюзї становив у обстежених пацієнтів від 0,1 с до 0,63 с. Він перевищував референтне

Таблиця 2. Медіанні значення показників змикання та розмикання зубів (с), а також індексу асиметрії у групах порівняння залежно від способу фіксації уламків

\begin{tabular}{|l|c|c|c|c|c|}
\hline \multicolumn{1}{|c|}{$\begin{array}{c}\text { Досліджуваний } \\
\text { показник }\end{array}$} & $\begin{array}{c}\text { Середні показ- } \\
\text { ники за даними } \\
\text { літератури }\end{array}$ & $\begin{array}{c}\text { Gr1 } \\
(\mathrm{n}=6)\end{array}$ & $\begin{array}{c}\mathrm{Gr} 2 \\
(\mathrm{n}=5)\end{array}$ & $\begin{array}{c}\text { Gr3 } \\
(\mathrm{n}=7)\end{array}$ & $\begin{array}{c}\text { Рівень значущості } \\
\text { різиці між показ- } \\
\text { никами, } \\
\mathrm{p}\end{array}$ \\
\hline $\begin{array}{l}\text { Occlusion time час } \\
\text { оклюзії (c) } \\
\text { Ме }\left(\mathrm{Q}_{\mathrm{I}} \div \mathrm{Q}_{\mathrm{III}}\right)\end{array}$ & $<0,3$ & $\begin{array}{c}0,17 \\
(0,12 \div 0,25)\end{array}$ & $\begin{array}{c}0,29 \\
(0,18 \div 0,37)\end{array}$ & $\begin{array}{c}0,22 \\
(0,21 \div 0,38)\end{array}$ & 0,468 \\
\hline $\begin{array}{l}\text { Disclusion time час } \\
\text { дезоклюзії (c) } \\
\text { Ме }\left(\mathrm{Q}_{\mathrm{I}} \div \mathrm{Q}_{\mathrm{III}}\right)\end{array}$ & $<0,4$ & $\begin{array}{c}0,18 \\
(0,15 \div 0,19)\end{array}$ & $\begin{array}{c}0,13 \\
(0,12 \div 0,20)\end{array}$ & $\begin{array}{c}0,11 \\
(0,08 \div 0,22)\end{array}$ \\
\hline $\begin{array}{l}\text { Iндекс асиметрії (\%) } \\
\text { Ме }\left(\mathrm{Q}_{\mathrm{I}} \div \mathrm{Q}_{\mathrm{III}}\right)\end{array}$ & $\begin{array}{c}12,2 \\
(8 \div 29,1)\end{array}$ & $\begin{array}{c}28,4 \\
(16,8 \div 36,8)\end{array}$ & $\begin{array}{c}23,2 \\
(15,4 \div 29,7)\end{array}$ & 0,61 \\
\hline
\end{tabular}

Примітка. ${ }^{1}$ - дані, отримані з літературних джерел [20]. 


\section{Хірургічна стоматологія}

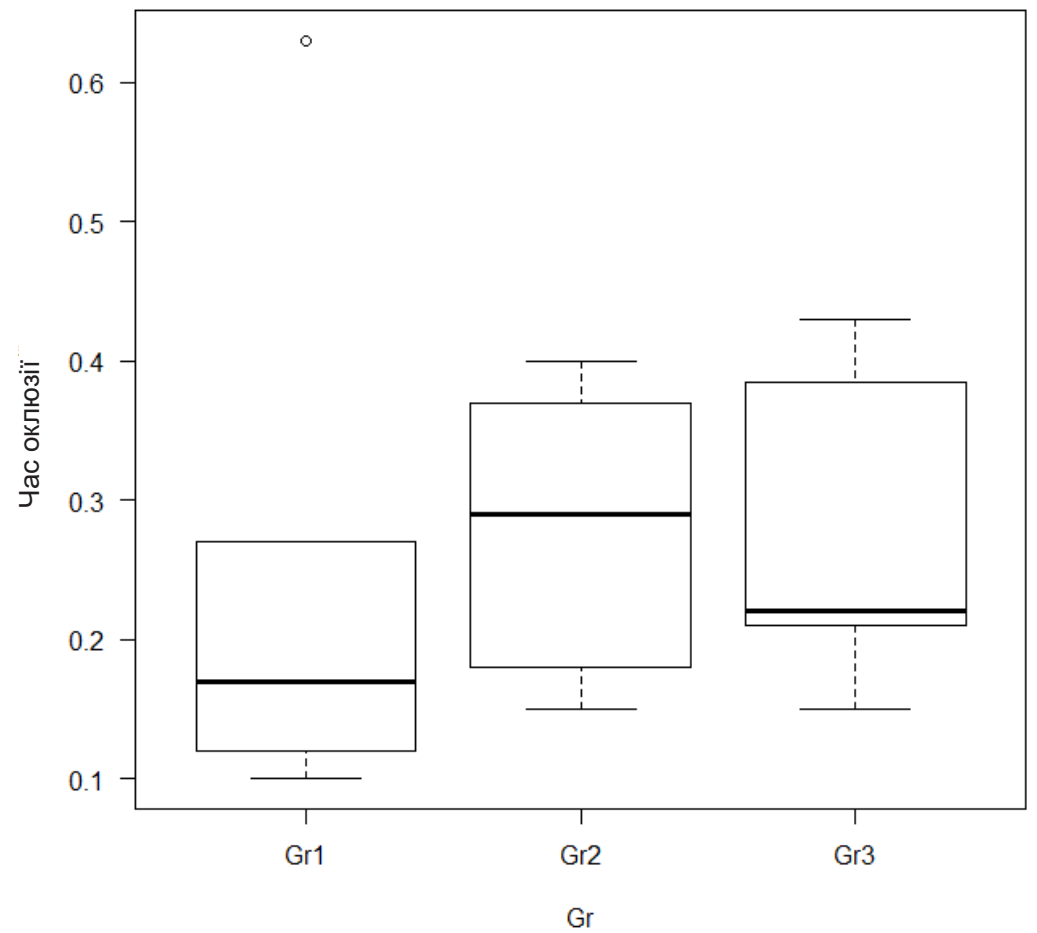

Рис. 4. Медіанні значення показників часу оклюзії у групах порівняння залежно від способу фіксації уламків. Порівняння показника проводили за критерієм Краскела - Уолліса, попарні порівняння проводили за критерієм Стіла -Двасса.

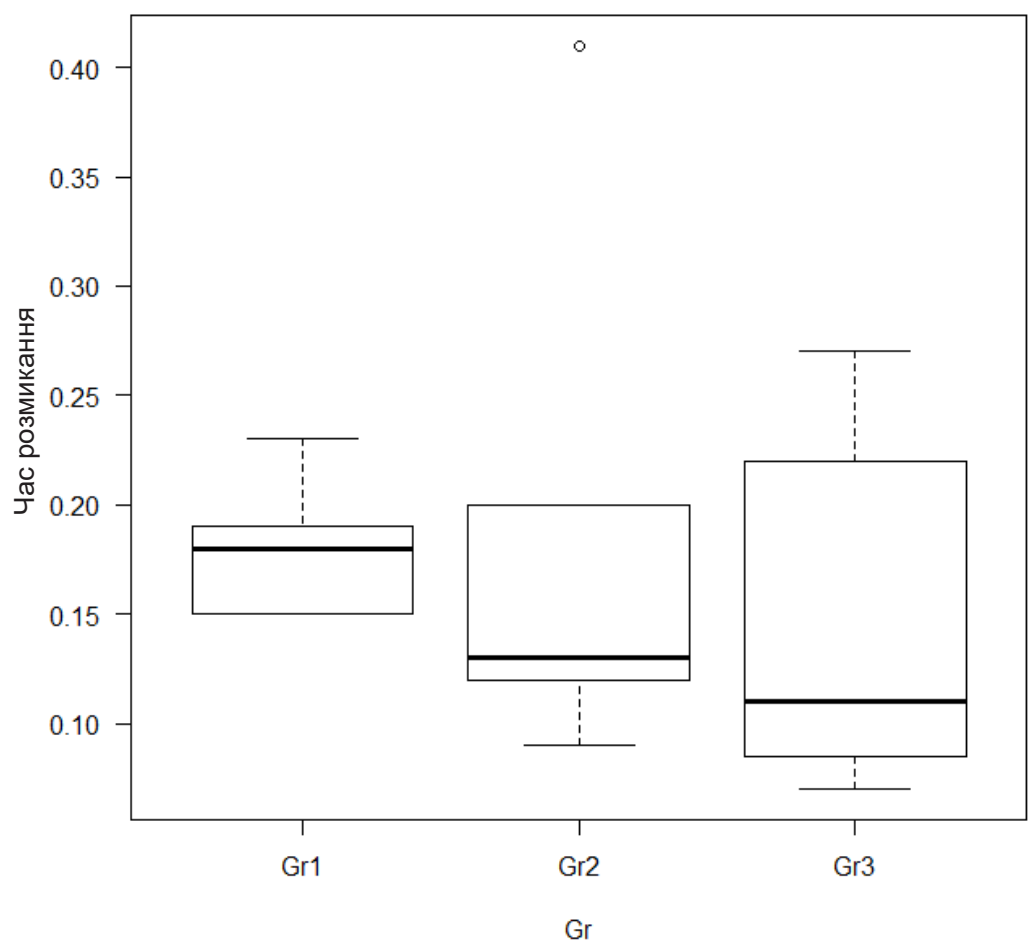

Рис. 5. Медіанні значення показників часу дезоклюзії у групах порівняння залежно від способу фіксації уламків. Порівняння показника проводили за критерієм Краскела - Уолліса, попарні порівняння проводили за критерієм Стіла -Двасса. 
Хірургічна стоматологія

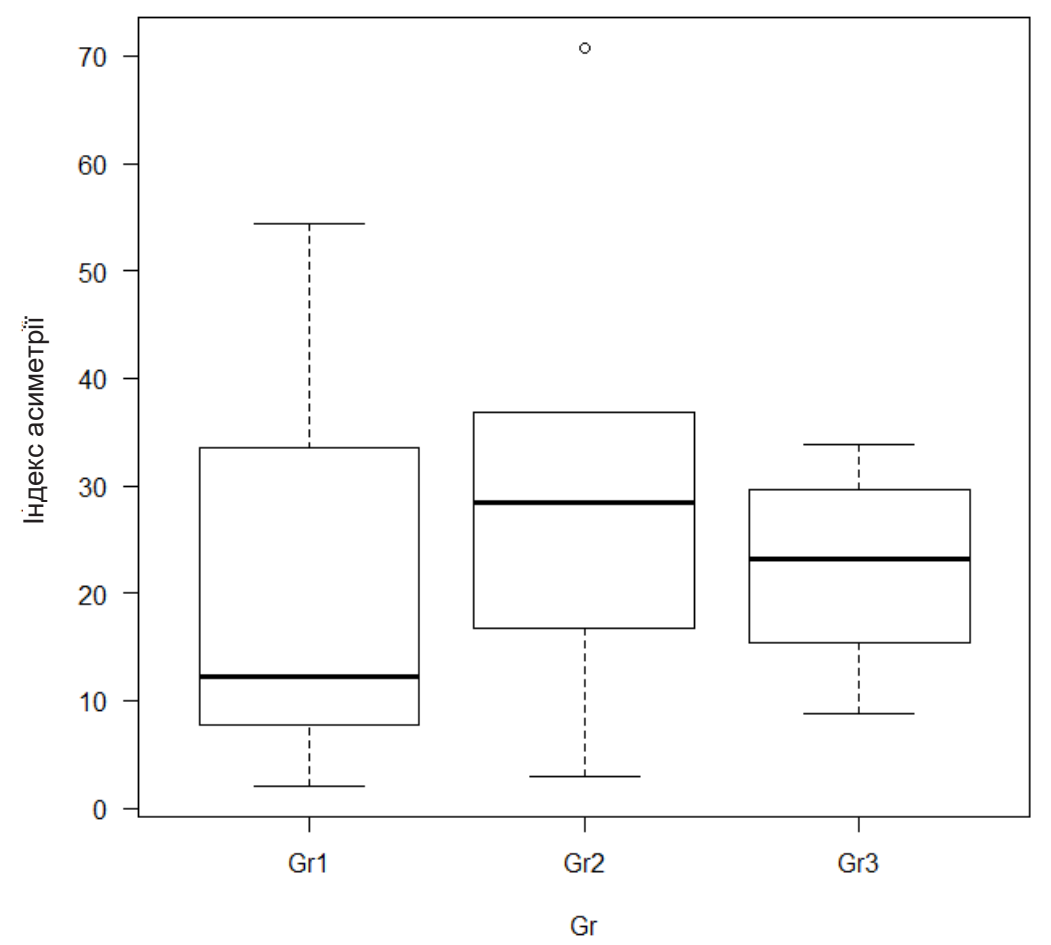

Рис. 6. Медіанні значення показника індексу асиметрії оклюзії у групах порівняння залежно від способу фіксації уламків. Порівняння показника проводили за критерієм Краскела - Уолліса, попарні порівняння проводили за критерієм Стіла - Двасса.

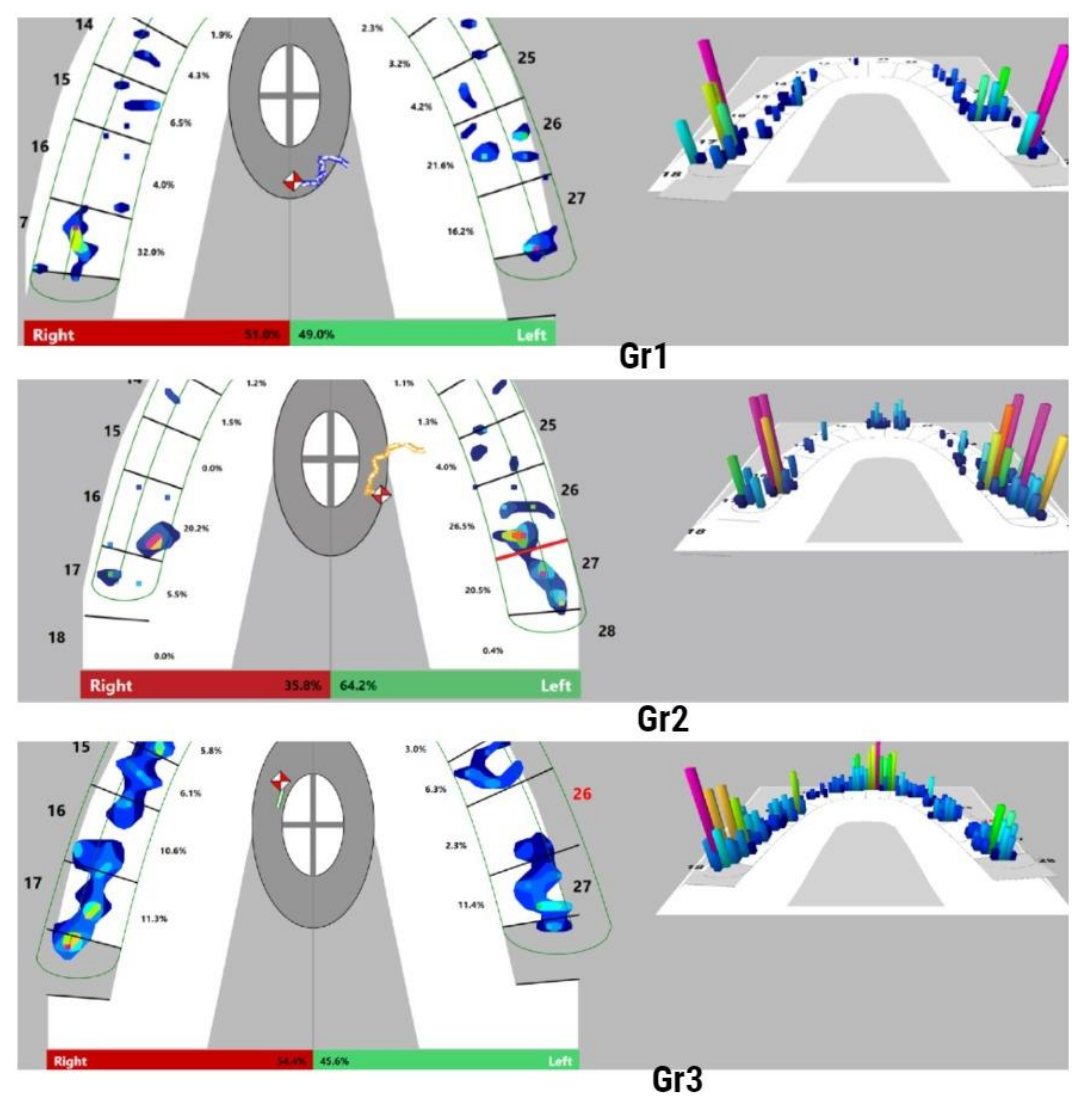

Рис. 7. Графічне двовимірне та тривимірне зображення зображення розташування, сили оклюзійних контактів, балансу оклюзії у групах порівняння, отримане за допомогою програмного забезпечення «T-Scan» компанії «Tekscan» (Tekscan, Inc., S. Boston, MA, CШA). 
значення 0,3 с у 1 хворого першої групи (16,7 \%) i в 5 (42 \%) хворих другої і третьої груп, де були наявні уламкові переломи, що супроводжувались утворенням дефектів вертикальних контрфорсів. Водночас у третій групі час оклюзії у середньому був меншим на 25 \%, ніж в другій групі, а індекс асиметрії був нижче $19 \%$, що свідчило про краще відновлення жувальної функції у пацієнтів, яким для заміщення дефектів контрфорсів застосовували аутотрансплантацію кістки. Час дезоклюзії в обстежених хворих становив 0,07 с до 0,43 с і характеризувався значною варіативністю. Достовірних розбіжностей за цим показником в групах порівняння виявлено не було.

Крім власне оклюзійних співвідношень на досліджені показники суттєво впливає стан жувальних м'язів, що можуть ушкоджуватись при травмі, але, ще більшою мірою, при забезпеченні хірургічних доступів під час проведення остеосинтезу. Взявши до уваги нерівномірність груп, різницю в будові кісток лицевого скелета серед пацієнтів груп дослідження, складність стандартизації однорідності вибірки ми провели порівняння показників часу оклюзії, дезоклюзії та індексу асиметрії, виділивши дві групи, врахувавши наявність переломів нижньої щелепи, що супроводжувались їх відшаруванням або пересіченням та/або проведення біфронтального доступу під час хірургічного лікування переломів верхньої щелепи та кісток середньої зони обличчя, що супроводжувалось оголенням скроневих м’язів, що, у свою чергу, могло призводити до порушення роботи м’язів, і як наслідок, погіршувати стан оклюзійних співвідношень пацінта.

У результаті відбору було виділено 2 групи пацієнтів. До першої групи увійшло 6 пацієнтів, яким проводилось лікування переломів нижньої щелепи та/або проведення біфронтального доступу (Gr1). До другої групи віднесли 12 пацієнтів, яким проводили лікування переломів верхньої щелепи за стандартною методикою без використання відшарування (оголення) жувальних м'язів (Gr2). Хоча статистично достовірної різниці між показниками в цих групах виявлено не було через малу кількість спостережень. Відзначалась чітка тенденція до зростання часу оклюзії на $24 \%$, часу дезоклюзії - на 16 \% та ступеня асиметрії - на 17 \% у пацієнтів із операційною травмою скроневого чи/або власне жувального м’яза.

Дані порівняння показників наведені у таблиці 3 та на рисунках 8-10.

Дискусія. Забезпечення ефективної функції жування $є$ складним регульованим процесом, що забезпечується унікальною анатомічною будовою щелепно-лицевої ділянки та злагодженою роботою різних анатомічних структур. При травмі окремі елементи цієї системи можуть зазнавати руйнування, що спричиняє дезінтеграцію усієї системи. Завданням хірургічного лікування переломів верхньої щелепи є відновлення цілості ушкоджених кісток і претравматичних оклюзійних співвідношень, а також швидке відновлення функції СНЩС і жувальних м’язів у процесі реабілітації. Забезпечення множинного міжзубного контакту, що є одним із показників центральної оклюзії у нормі, під час проведення остеосинтезу $€$ важливим завданням, що досягається низкою хірургічних прийомів і $€$ важливим критерієм ефективності лікування в цілому. Втім у віддаленому післяопераційному періоді на ефективність відновлення функції жування впливає і низка інших чинників, таких, як стан м’язового апарату пародонта і твердих тканин зубів (наявність сколів, переломів, каріозних уражень тощо), утворення дефектів зубних рядів, у тому числі внаслідок дентоальвеолярної травми, якість регенерату, що утворився на ділянці перелому й особливості розподілу напружень

Таблиця 3. Медіанні значення показників змикання та розмикання зубів (с), а також індексу асиметрії у групах порівняння залежно від використаних хірургічних доступів

\begin{tabular}{|c|c|c|c|}
\hline Досліджуваний показник & $\begin{array}{c}\text { Пацієнти, яким для до- } \\
\text { ступу до зон перелому } \\
\text { пересікали і відшаровува- } \\
\text { ли жувальні м’язи } \\
\text { Gr1 }\end{array}$ & $\begin{array}{c}\text { Пацієнти, у яких при про- } \\
\text { веденні остеосинтезу хі- } \\
\text { рургічної травми жуваль- } \\
\text { них м’язів не відбувалось } \\
\text { Gr2 }\end{array}$ & $\begin{array}{c}\text { Рівень значущості } \\
\text { різниці між показни- } \\
\text { ками, } \\
\text { р }\end{array}$ \\
\hline $\begin{array}{l}\text { Occlusion time (c) } \\
\operatorname{Me}\left(Q_{I} \div Q_{I I I}\right)\end{array}$ & $\begin{array}{c}0,29 \\
(0,22 \div 0,37)\end{array}$ & $\begin{array}{c}0,22 \\
(0,15 \div 0,39)\end{array}$ & 0,78 \\
\hline $\begin{array}{l}\text { Disclusion time (c) } \\
\operatorname{Me}\left(Q_{I} \div Q_{\text {III }}\right)\end{array}$ & $\begin{array}{c}0,19 \\
(0,12 \div 0,25) \\
\end{array}$ & $\begin{array}{c}0,16 \\
(0,11 \div 0,19) \\
\end{array}$ & 0,578 \\
\hline $\begin{array}{l}\text { Індекс асиметрії (\%) } \\
\operatorname{Me}\left(Q_{I} \div Q_{I I I}\right)\end{array}$ & $\begin{array}{c}33,6 \\
(31,2 \div 31,8)\end{array}$ & $\begin{array}{c}16,7 \\
(10,1 \div 28,3)\end{array}$ & 0,287 \\
\hline
\end{tabular}




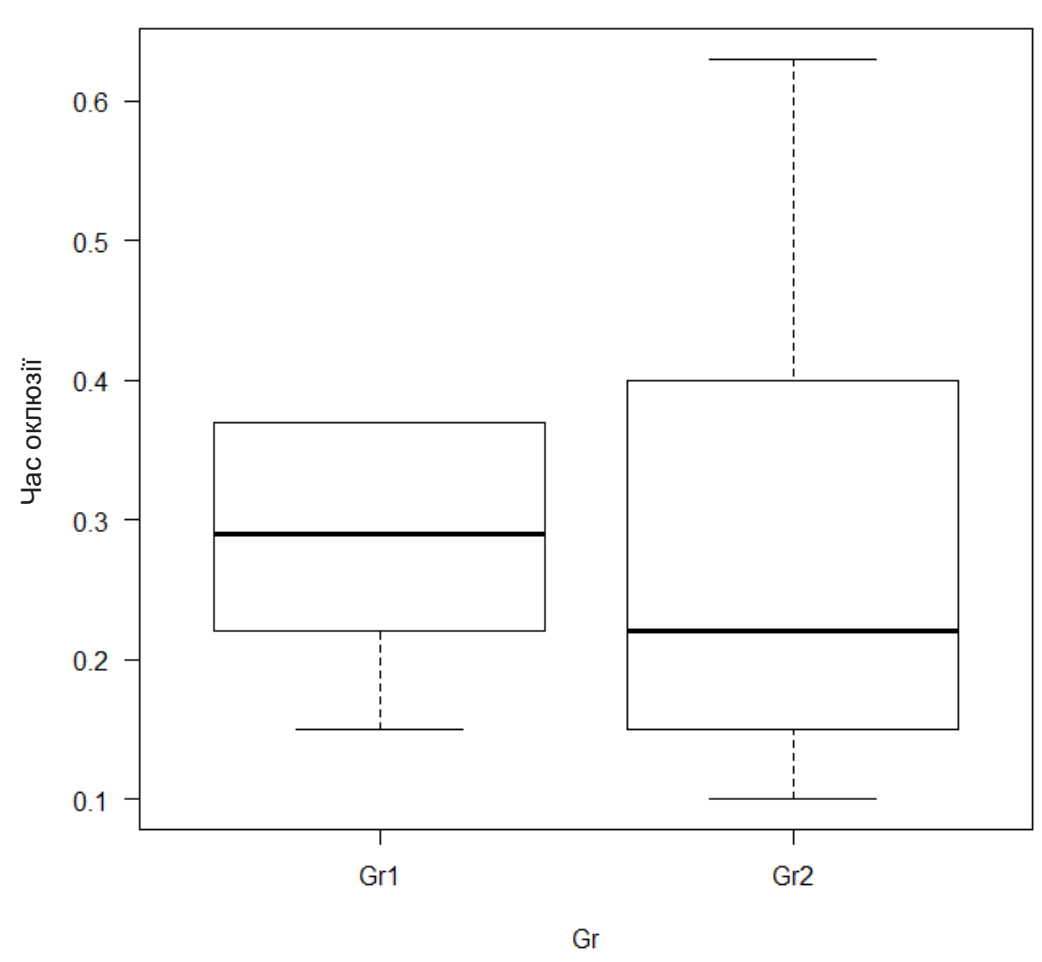

Рис. 8. Медіанні значення показників часу оклюзії у групах порівняння залежно від використаних хірургічних доступів. Порівняння показника проводили за критерієм Краскела - Уолліса, попарні порівняння проводили за критерієм Стіла - Двасса.

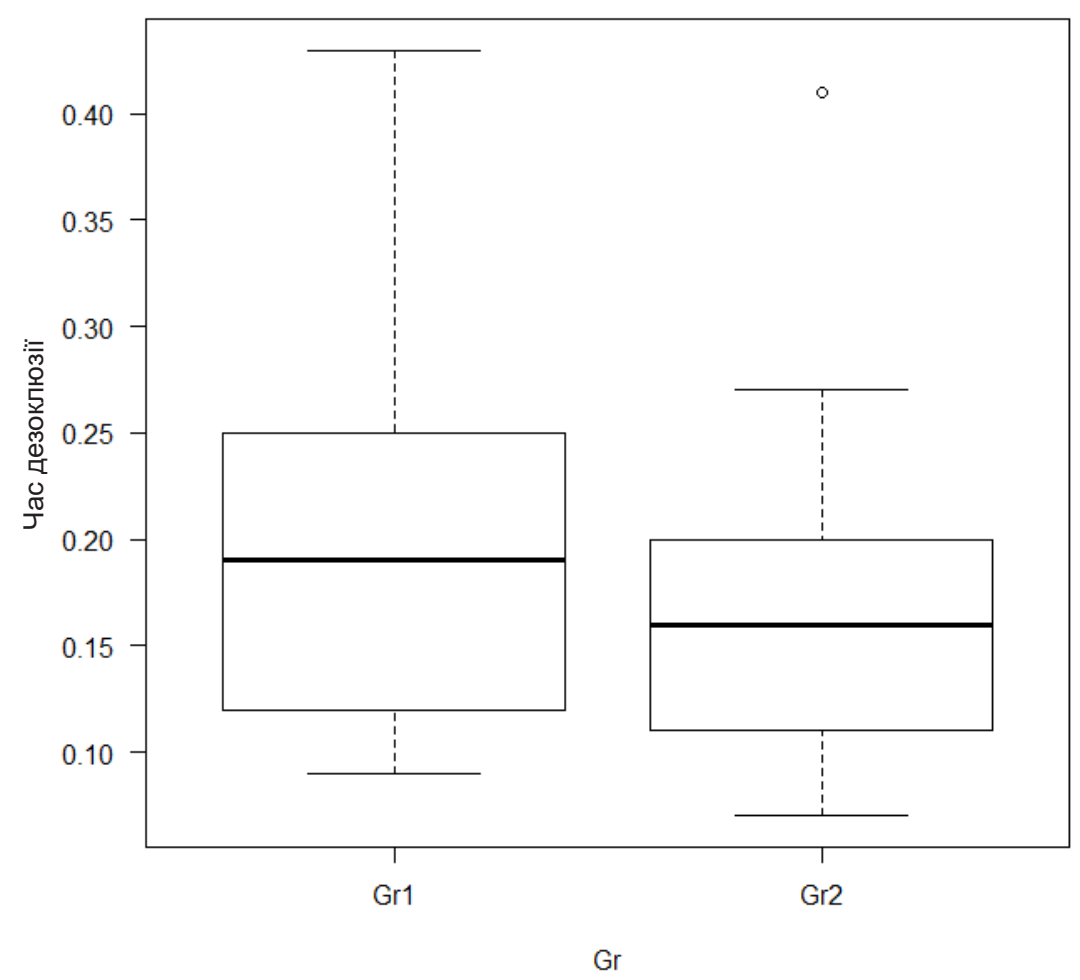

Рис. 9. Медіанні значення показників часу дезоклюзії у групах порівняння залежно від використаних хірургічних доступів. Порівняння показника проводили за критерієм Краскела - Уолліса, попарні порівняння проводили за критерієм Стіла - Двасса. 


\section{Хірургічна стоматологія}

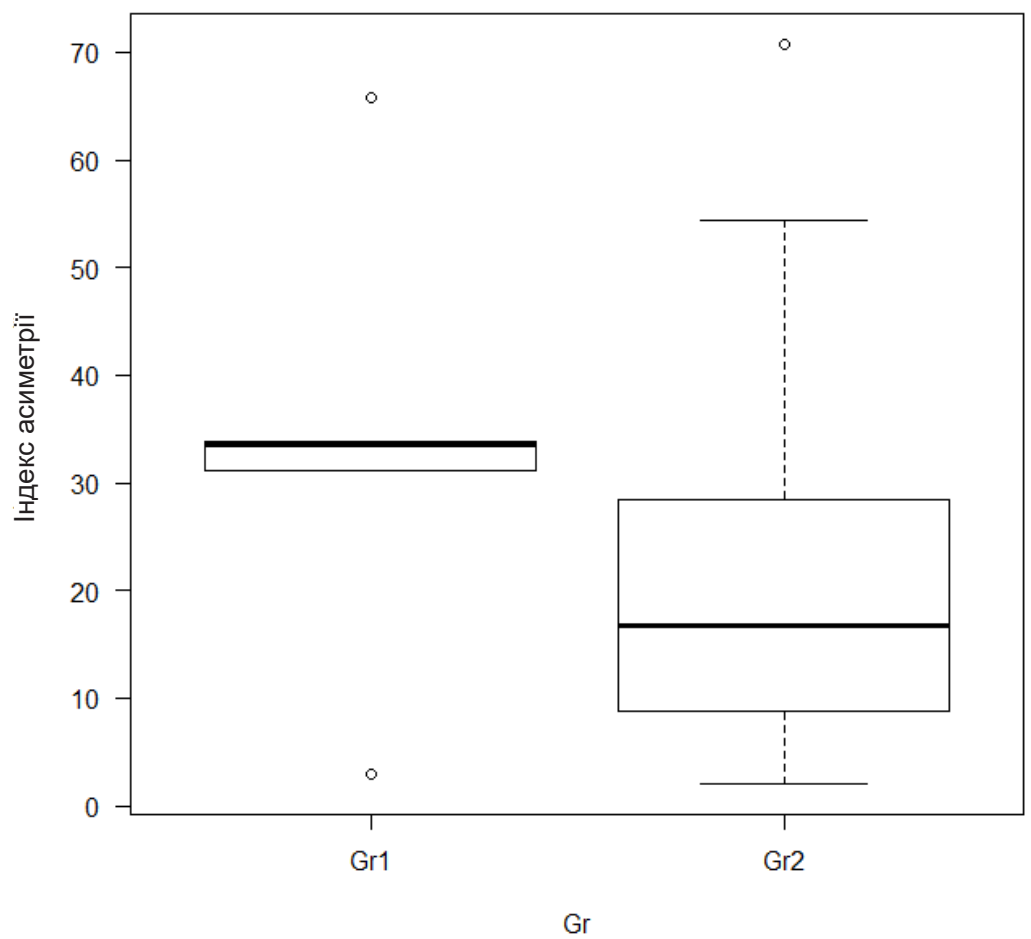

Рис. 10. Медіанні значення показника індексу асиметрії у групах порівняння залежно від використаних хірургічних доступів. Порівняння показника проводили за критерієм Краскела - Уолліса, попарні порівняння проводили за критерієм Стіла - Двасса.

і деформацій у системі фіксатор - кістка, що залежать від застосованого способу остеосинтезу.

У роботах Шуминського та ін. (2020); McRaeet al. (2000); Erkmen et al. (2009) показано, що одним із вагомих факторів, у випадку переломів верхньої щелепи, є стабільність уламків, спосіб їх фіксації та відновлення опірної спроможності контрфорсів, що забезпечують здатність кістки протидіяти жувальному навантаженню, сприймаючи і перерозподіляючи його на інші структури лицевого і мозкового черепа [11, 21]. Неможливість ефективного відновлення природних біомеханічних параметрів верхньої щелепи теоретично може супроводжуватись зниженням сили довільного змикання зубів, асиметрією в балансі оклюзії, зміною жувального стереотипу та появою аномальних контактів у різних фазах жувального циклу (особливо, коли зниження жорсткості й міцності системи супроводжується пластичними деформаціями елементів фіксаціі та вторинними зміщеннями).

Ці питання в літературі розглядались переважно у теоретичному аспекті, й на відміну від переломів НЩ, де існує велика кількість робіт, присвячених відновленню оклюзійних та артикуляційних співвідношень та ризику м'язовосуглобових дисфункцій у посттравматичному періоді, для ВЩ подібних досліджень практично не проводилось. Отримані дані свідчать, що переломи верхньої щелепи були асоційовані з підвищеним ризиком оклюзійних порушень у післяопераційному періоді, зокрема наявності супраконтактів та контактів надмірної сили, асиметрії у балансі оклюзії в момент максимального міжгорбкового змикання, що спостерігали у всіх хворих, подовження часу оклюзії (збільшення із виходом за межі референтних значень у 30 \% пацієнтів) тощо. Одним із обмежень даного дослідження є те, що претравматичний стан оклюзії у пацієнтів був невідомий, тому ми не можемо чітко визначити, якою мірою саме травма і наслідки хірургічного втручання визначали розвиток цих порушень. Однак отримані дані свідчать, що пацієнти із переломами ВЩ на етапах реабілітації потребують спостереження в ортопеда-стоматолога із проведенням відповідної діагностики і корекції вказаних порушень. Важливо, що за нашими даними зазначені порушення можуть носити субкомпенсований характер і не до кінця усвідомлюватись пацієнтом і щелепно-лицевим хірургом. Це може стати причиною несвоєчасного звернення за допомогою і поглиблення патологічних змін із часом. 
Переломи верхньої щелепи дуже різноманітні. На сьогодні найбільш вживаною їх класифікацією, що описує переломи верхньої щелепи та кісток середньої зони обличчя залишається класифікація Rene Le Fort, запропонована більше 100 років тому. Очевидно, що дана класифікація $€$ досить умовною: вона не дозволяє оцінити реальний характер руйнування вертикальних і горизонтальних контрфорсів, особливо у випадку багатоуламкових переломів, та часто недооцінює реальну тяжкість ушкодження, що являє собою складну комбінацію переломів вилицевого, назоетмоїдального комплексу та орбіт із ушкодженням верхніх щелеп (у тому числі в нетипових зонах локалізації) [14, 22, 23]. При високоенергетичній травмі руйнування вертикальних контрфорсів ВЩ, зокрема вилично-верхньощелепного і носолобового є дуже поширеним. 3 даних літератури відомо, що лінійні переломи, за умов їх адекватної фіксації щонайменше 4 титановими пластинами, за показниками міцності наближаються до інтактної верхньої щелепи [24]. Втім нерідко руйнування контрфорсів носить уламковий характер, виникає потреба видалення нежиттєздатних кісткових фрагментів і на ділянці ураження виникають дефекти - неперервність контрфорсів порушується.

За нашими даними, наявність дефекту на ділянці контрфорсів сприяє поглибленню функціональних змін, виявлених за результатами комп’ютерної оклюзіогрфії, зокрема супроводжується зростанням індексу асиметрії у середньому на 13,6 \% та часу оклюзіїі на 0,1 с. У ситуаціях, коли ураження носили асиметричний характер, і в пацієнта з одного боку був наявний перелом із дефектом, заміщений пластиною, а 3 іншого боку, - перелом фіксований без дефекту кістки (у тому числі при застосуванні кісткових трансплантатів), перші контакти завжди виникали на боці, де дефект контрфорсів був відсутній. Ступінь асиметрії у силі стискання зубів правого і лівого боків в цих випадках міг бути дуже значним, досягаючи 70 \%. При цьому бік першого контакту між зубами збігався з вектором сумарного оклюзійного навантаження у 77,8 \% випадків. Відомо, що під час лікування пацієнтів із розладами СНщС лікарі-стоматологи намагаються досягнути балансу оклюзії у співвідношенні 50:50 \% на обох половинах зубних рядів за допомогою механотерапії, фізіотерапії, корекції оклюзійних співвідношень, протезування тощо [25], оскільки збалансований двосторонній міжзубний контакт створює найсприятливіші умови для функціонування зубощелепної системи.
У випадку ПвЩ певні можливості для оптимізації жувальної функції розкриває застосування кісткових аутотрансплантатів для заміщення дефектів вертикальних контрфорсів. У модельному експерименті із застосуванням методу скінченних елементів було показано, що використання кісткових аутотрансплантатів для заміщення дефектів вертикальних контрфорсів верхньої щелепи при проведенні остеосинтезу дозволяє збільшити інтегральну жорсткість фіксації у середньому в 2 рази та зменшити еквівалентні напруження за Мізесом в елементах фіксації у середньому на 30 \%. Це досягалось за рахунок перерозподілу напружень і деформацій між пластиною та кісткою.

У даному дослідженні було показано, що заміщення дефектів вертикальних контрфорсів кістковими аутотрансплантатами покращує відновлення жувальної функції, порівняно із пацієнтами, де для фіксації уламків на ділянці дефектів використовували накісні міні-пластини як самостійне хірургічне рішення, зокрема зменшує середній час оклюзії у цієї категорії хворих на 25 \%, а індекс асиметрії - на 19 \%. Через невелику кількість спостережень і значні індивідувальні варіації за даними показниками в групах порівняння, ці розбіжності виявились не достовірними. Це вимагає подальшого вивчення питання на більших контингентах хворих, у тому числі в багатоцентрових рандомізованих дослідженнях. Крім того необхідно брати до уваги той факт, що крім точності відновлення претравматичної анатомії кісток обличчя та множинного фісурно-горбкового контакту зубів, важливим чинником нормалізації оклюзійних співвідношень є стан жувальних м'язів. У нашому дослідженні показано, що операційна травма жувальних м'язів при проведенні хірургічних доступів - пересічення і відшарування власне жувальних м'язів (при операціях із приводу супутніх травм нижньої щелепи) та скроневих м’язів (під час виконання вінцевого доступу спричиняє збільшення часу оклюзії у середньому на 24 \%, часу дезоклюзії - на 16 \% та ступеня асиметрії - на 17 \%, не залежно від способу остеосинтезу Вщ).

Таким чином, проведені дослідження свідчать про значну поширеність післяопераційних порушень жувальної функції та оклюзійних співвідношень у пацієнтів із ПВщ, що потребує підвищеної уваги як щелепно-лицевих хірургів, так i ортопедів-стоматологів. Порушення оклюзійних співвідношень залежать як від тяжкості травми, так і від особливостей обраної лікуваль- 
ної стратегії. Можливими шляхами зменшення вираження цих порушень є заміщення дефектів вертикальних контрфорсів ВЩ кістковими аутотрансплантатами і щадна міні-інвазивна техніка проведення доступів відносно жувальних м’язів поряд із ранньою мобілізацією НЩ у післяопераційному періоді.

Висновки. Переломи верхньої щелепи асоційовані з підвищеним ризиком оклюзійних порушень у післяопераційному періоді, зокрема наявності супраконтактів та контактів надмірної сили, асиметрія в балансі оклюзії у момент максимального міжгорбкового змикання, подовження часу оклюзії тощо.

Важливими чинниками, що сприяють поглибленню функціональних змін, виявлених за результатами комп’ютерної оклюзіогрфії, є переломи верхньої щелепи із дефектом (зростання індексу асиметрії в середньому на 13,6 \% та часу оклюзіїі на 0,1 c), а також операційна травма жувальних м'язів при проведенні хірургічних доступів (зростання часу оклюзї в середньому на
24 \%, часу дезоклюзії - на 16 \% та ступеня асиметрії - на 17 \%).

Заміщення дефектів вертикальних контрфорсів кістковими аутотрансплантатами покращує відновлення жувальної функції, порівняно із пацієнтами, де для фіксації уламків на ділянці дефектів використовували накісні міні-пластини як самостійне хірургічне рішення (середній час оклюзії у цієї категорії хворих був меншим на 25 \%, а індекс асиметрії нижче 19 \%).

Перспективи подальших досліджень. Дослідження актуальне, адже дозволяє порівняти та визначити ефективність способів відновлення контрфорсів верхньої щелепи, що, у свою чергу, упереджує порушення прикусу в ранньому та пізньому післяопераційному періодах. Актуальна проблема стандартизації вибірок, адже однакові умови переломів з обох боків зустрічаються вкрай рідко. Отримання статистично достовірної різниці показників потребує збільшення вибірки пацієнтів та проведення подальших мультицентрових досліджень.

\section{(CЕ. В. Шуминский ${ }^{1}$, А. В. Копчак ${ }^{1}$, В. Г. Гурьянов ${ }^{1}$, Н. В. Лисейко ${ }^{1}$,} Е. Н. Дорошенко ${ }^{2}$

Национальный медицинский университет имени А. А. Богомольца, г. Киев

Национальный университет здравоохранения Украины имени П. Л. Шупика, г. Киев²

\section{Оценка окклюзионных соотношений и жевательной функции у пациентов с переломами верхней челюсти методом компьютерной окклюзиографии}

Резюме. Осколочные переломы верхней челюсти на участке вертикальных контрфорсов затрудняют процесс репозиции и фиксации, создают предпосылки для развития глубоких функциональных нарушений в раннем и отдаленном посттравматическом периоде. Восстановление их с помощью накостных титановых пластин является основной задачей лечения данной категории пациентов.

Цель исследования - исследовать характер окклюзионных соотношений и определить их изменения у пациентов с травматическими переломами верхней челюсти в зависимости от примененного способа реконструкции вертикальных контрфорсов с использованием метода компьютерной окклюзиографии.

Материалы и методы. Исследовано 18 пациентов с множественными переломами костей средней зоны лица (15 мужчин и 3 женщин). Средний возраст $(43,8 \pm 10,8)$ г. Окклюзиографии проведенные в группах с линейными переломами (Gr1, n=6), с костными дефектами в области вертикальных контрфорсов (Gr2, n=5) и с восстановленными контрфорсами с помощью костных аутотрансплантатов (Gr3, n=7). Анализ проведен с помощью аппарата и программного обеспечения «T-Scan» компании «Tekscan» (Tekscan, Inc., S. Boston, MA, США). Исследованы время окклюзии, дезокклюзии, индекс асимметрии окклюзии.

Результаты исследований и их обсуждение. Медианные значения времени окклюзии, дезокклюзии, индекса асимметрии Gr1- $(0,17(0,12 \div 0,25), 0,18(0,15 \div 0,19), 12,2 \%(8 \div 29,1) \%)) ; \mathrm{Gr} 2-(0,29(0,18 \div 0,37), 0,13$ $(0,12 \div 0,20), 28,4 \%(16,8 \div 36,8) \%)$; Gr3 - $(0,22(0,21 \div 0,38), 0,11(0,08 \div 0,22), 23,2 \%(15,4 \div 29,7) \%)$ соответственно. Определялась тенденция к росту времени окклюзии на $24 \%$, времени дезокклюзии - на $16 \%$ и степени асимметрии - на 17 \% у пациентов с переломами нижней челюсти, сопровождающиеся отслоением или пересечением жевательных мышц и у пациентов, которым проводился бифронтальний доступ, что сопровождалось обнажением височных мышц для лечения переломов костей средней зоны лица. 
Выводы. Факторами, способствующими ухудшению функциональных изменений, являются переломы верхней челюсти с дефектом (рост индекса асимметрии в среднем на 13,6 \% и времени окклюзиии - на 0,1 с), а также операционная травма жевательных мышц при проведении хирургических доступов. Замещение дефектов вертикальных контрфорсов костными аутотрансплантатами улучшает восстановление жевательной функции по сравнению с пациентами, где для фиксации отломков на участке дефектов использовали накостные мини-пластины, как самостоятельное хирургическое решение (среднее время окклюзии у этой категории больных было меньше на 25 \%, а индекс асимметрии - на $19 \%)$.

Ключевые слова: Le Fort; переломы верхней челюсти; Tscan; окклюзиография; контрфорс.

\section{CYe. V. Shumynskyi ${ }^{1}$, A. V. Kopchak ${ }^{1}$, V. H. Huryanov ${ }^{1}$, N. V. Lyseyko ${ }^{1}$, O. M. Doroshenko²}

O. O. Bohomolets National Medical University, Kyiv ${ }^{1}$

Shupyk National Healthcare University of Ukraine ${ }^{2}$

\section{Evaluation of occlusal ratios and masticatory function in patients with maxillary fractures by digital analysis system}

Summary. Comminuted maxillary fractures in the area of vertical buttresses complicate the process of reduction and fixation, create preconditions for the development of deep functional disorders in the early and late post-traumatic period. Their restoration with the titanium miniplates is the main treatment task of this category of patients.

The aim of the study - to investigate occlusal relationships and determine their changes in patients with maxillary fractures, depending on the applied method of reconstruction of vertical buttresses using digital analysis of occlusion.

Materials and Methods. The study involved 18 patients with multiple midface fractures (15 men and 3 women). Average age $43.8 \pm 10.8 \mathrm{~g}$. Analysis of occlusion performed in groups with linear fractures $(\mathrm{Gr} 1, \mathrm{n}=6)$, with bone defects in the area of vertical buttresses $(\mathrm{Gr} 2, \mathrm{n}=5)$ and with restored buttresses using bone autografts (Gr3, n=7). The analysis was carried out using the apparatus and software "T-Scan" company "Tekscan" (Tekscan, Inc., S. Boston, MA, USA). The time of occlusion, disocclusion, and the index of occlusion asymmetry were investigated.

Results and Discussion. Median values of occlusion time, disocclusion, asymmetry index Gr1- $(0.17(0.12 \div$

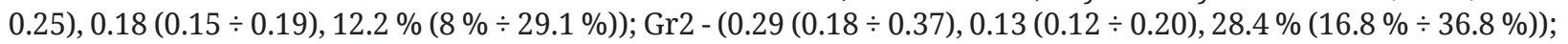
Gr3 - (0.22 (0.21 $\div 0.38), 0.11(0.08 \div 0.22), 23.2 \%(15.4 \% \div 29.7 \%)$ ) respectively. There was a tendency to increase the occlusion time by $24 \%$, disocclusion time by $16 \%$ and the degree of asymmetry by $17 \%$ in patients with mandibular fractures accompanied by detachment or cutting of the masticatory muscles and in patients with coronal approach accompanied by exposure of the temporal muscles for the treatment of midface bones fractures.

Conclusions. 1. Factors contributing to worsening functional changes are fractures of the maxilla with defects in the area of vertical buttresses (asymmetry index growth by an average of $13.6 \%$ and occlusion time by $0.1 \mathrm{~s}$ ), also, trauma of masticatory muscles during the surgical approach. 2. Replacement of vertical buttresses defects with bone autografts improves the restoration of masticatory function in comparison with patients where miniplates were used to fix the fragments at the site of defects, as an independent surgical solution (the mean time of occlusion in this category of patients was $25 \%$ less, and the asymmetry index was less by $19 \%$ ).

Key words: Le Fort; maxillary fractures; Tscan; occlusiography; buttress.

\section{СПИСОК ЛІТЕРАТУРИ}

1. Лихота К. М. Оцінка оклюзійних співвідношень зубо-щелепної системи у пацієнтів із сагітальними аномаліями прикусу методом комп’ютерної оклюзіографії / К. М. Лихота // Збірник наукових праць співробітників НМАПО ім. П. Л. Шупика. - 2015. Вип. 24 (3). - С. 43-50.
2. Федорова О. В. Можливості використання системи комп’ютерного аналізу оклюзійних контактів при ортопедичному лікуванні пацієнтів із вторинними зубощелепними деформаціями (огляд літератури) / О. В. Федорова // Український стоматологічний альманах. - 2017. - № 3. - С. 49-52. 
3. Patient satisfaction after open reduction and internal fixation of zygomatic bone fractures / M. Kurita, M. Okazaki, M. Ozaki [et al.] // J. Craniofac. Surg. - 2010. Vol.21(1).-P.45-49.DOI:10.1097/SCS.0b013e3181c36304. 4. A ten year analysis of the traumatic maxillofacial and brain injury patient in Amsterdam: complications and treatment / E. G. Salentijn, J. D. Collin, P. Boffano, T. Forouzanfar // J. Craniomaxillofac. Surg. - 2014. - Vol. 42 (8). - P. 1717-1722. DOI: 10.1016/j.jcms.2014.06.005.

5. Determination of individual cephalometric characteristics of the occlusal plane in Ukrainian young men and young women with orthognatic bite / M. O. Dmitriev, I. V. Gunas, I. V. Dzevulska, I. V. Zhulkevych // Biomedical and Biosocial Anthropology. - 2018. - No. 33. - P. 5-11. DOI: 10.31393/bba33-2018-01.

6. Dynamical changes of occlusion and articulation during treatment of mandibular angle fractures / A. Baltrusaityte, A. Surna, G. Pileicikiene [et al.] // Stomatologija. - 2013. - Vol. 15 (1). - P. 12-19.

7. Zachariades N. Complications associated with rigid internal fixation of facial bone fractures / N. Zachariades, I. Papademetriou, G. Rallis // J. Oral Maxillofac. Surg. - 1993. - Vol. 51 (3). - P. 275-279. DOI: 10.1016/ s0278-2391(10)80174-0.

8. Manson P. N. Some thoughts on the classification and treatment of Le Fort fractures / P. N. Manson // Ann. Plastic Surg. - 1986. - Vol. 17 (5). - P. 356-363. DOI: 10.1097/00000637-198611000-00003.

9. Kühnel T. S. Traumatologie des mittelgesichts / T. S. Kühnel, T. E. Reichert // Laryngorhinootologie. 2015. - Vol. 94 (Suppl. 1). - P. S206-247. DOI: 10.1055/s0034-1396873.

10. Maddux S. D. Zygomaticomaxillary morphology and maxillary sinus form and function: how spatial constraints influence pneumatization patterns among modern humans / S. D. Maddux, L. N. Butaric // Anat. Rec. (Hoboken). - 2017. - Vol. 300 (1). - P. 209-225. DOI: $10.1002 /$ ar.23447.

11. Шуминський $€$. В. Біомеханічний аналіз методів відновлення цілісності вертикальних контрфорсів верхньої щелепи при травматичних переломах кісток середньої зони обличчя із використанням індивідуалізованих скінченно-елементних моделей / Є. В. Шуминський, М. Г. Крищук, А. В. Копчак // Вiсник стоматології. - 2020. - № 4 (113). - С. 72-78.

12. McRae M. Midface fractures / M. McRae, J. Frodel // Facial. Plast. Surg. - 2000. - Vol. 16 (2). - P. 107-113. DOI: $10.1055 / \mathrm{s}-2000-12572$.

13. АO CMF. - Режим доступу : https://aocmf.aofoundation.org.

14. The Le Fort system revisited: Trauma velocity pre- dicts the path of Le Fort I fractures through the lateral buttress / G. Roumeliotis, R. Ahluwalia, T. Jenkyn, A. Yazdani // Plast. Surg. (Oakv). - 2015. - Vol. 23 (1). P. 40-42. DOI: 10.4172/plastic-surgery.1000899.

15. Decision-making algorithm in treatment of the atrophic mandible fractures / F. De Feudis, M. De Benedittis, V. Antonicelli [et al.] // G. Chir. - 2014. Vol. 35 (3-4). - P. 94-100.

16. Kopchak A. Relation between paranasal sinuses and surrounding bone tissue / A. Kopchak, Ie. Shumynsky // J. Educ. Health Sport. - 2020. - Vol. 10 (12). - P. 22-31. DOI: 10.12775/JEHS.2020.10.12.002.

17. Application of a facial injury severity scale in craniomaxillofacial trauma / S. C. Bagheri, E. J. Dierks, D. Kademani [et al.] // J. Oral Maxillofac. Surg. - 2006. Vol. 64 (3). - P. 408-414. DOI: 10.1016/j.joms.2005.11.013. 18. Біда О. В. Диференційовані методи ортопедичного лікування та фукнкціональної реабілітації хворих 3 дефектами зубних рядів, ускладнених зубощелепними деформаціями : кваліфікована наукова праця на правах рукопису дис. на здобуття наук. ступеня д-ра наук / О. В. Біда. - Івано-Франківськ : Івано-Франківський НМУ, 2018. - 390 с.

19. Kanda Y. Investigation of the freely available easyto-use software 'EZR' for medical statistics / Y. Kanda // Bone Marrow Transplant. - 2013. - Vol. 48. - P. 452-458. 20. Prafulla T. Digital analysis of occlusion using T-Scan III in orthodontics / T. Prafulla // Journal of Indian Orthodontic Society. - 2016. - Vol. 50 (3). - P. 196. DOI: 10.4103/0301-5742.186386.

21. Comparison of biomechanical behaviour of maxilla following Le Fort I osteotomy with 2- versus 4-plate fixation using 3D-FEA: part 3: inferior and anterior repositioning surgery / E. Erkmen, M. S. Ataç, E. Yücel, A. Kurt // Int. J. Oral Maxillofac. Surg. - 2009. - Vol. 38 (2). - P. 173179. DOI: 10.1016/j.ijom.2008.10.006.

22. Le Fort R. Experimental study of fractures of the upper jaw Parts I and II / R. Le Fort // Rev. Chir. Paris. 1901. - Vol. 23. - P. 208.

23. Marciani R. D. Management of midface fractures: fifty years later / R. D. Marciani // J. Oral. Maxillofac. Surg. - 1993. - Vol. 51 (9). - P. 960-968. DOI: 10.1016/ s0278-2391(10)80035-7.

24. Biomechanical evaluation of Le Fort I maxillary fracture plating techniques / H. Wang, M. S. Chen, Y. B. Fan [et al.] // J. Oral Maxillofac. Surg. - 2007. - Vol. 65 (6). P. 1109-1116. DOI: 10.1016/j.joms.2006.10.020.

25. Sutter B. A. Incidence of headaches related to occlusion and bite force imbalance: a case study / B. A. Sutter // Cranio. - 2016. - Vol. 34 (3). - P. 195-207. DOI: 10.1179/2151090315Y.0000000006. 


\section{REFERENCES}

1. Lykhota, K.M. (2015). Otsinka okliuziinykh spivvidnoshen zubo-shchelepnoi systemy u patsiientiv iz sahitalnymy anomaliiamy prykusu metodom kompiuternoi okliuziohrafii [Evaluation of occlusal ratios of the dental-maxillary system in patients with sagittal occlusion anomalies by computer occlusion]. Zbirnyk naukovykh prats spivrobitnykiv NMAPO im. P. L. Shupyka-Coll. of Sci. Works of employees of P. L. Shupyk NMAPE, 24 (3), 43-50 [in Ukrainian].

2. Fedorova, O.V. (2017). Mozhlyvosti vykorystannia systemy kompiuternoho analizu okliuziinykh kontaktiv pry ortopedychnomu likuvanni patsiientiv iz vtorynnymy zuboshchelepnymy deformatsiiamy (ohliad literatury) [Use of computer analysis of occlusal contacts in orthopedic patients with secondary deformities of dentition (literature review)]. Ukrayinskyi stomatolohichnyi almanakh - Ukrainian Dental Almanac, 3, 49-52 [in Ukrainian].

3. Kurita, M., Okazaki, M., Ozaki, M., Tanaka, Y., Tsuji, N., Takushima, A., \& Harii, K. (2010). Patient satisfaction after open reduction and internal fixation of zygomatic bone fractures. J. Craniofac. Surg., 21 (1), 45-49. DOI: 10.1097/SCS.0b013e3181c36304.

4. Salentijn, E.G., Collin, J.D., Boffano, P., \& Forouzanfar, T. (2014). A ten year analysis of the traumatic maxillofacial and brain injury patient in Amsterdam: complications and treatment. J. Craniomaxillofac. Surg., 42 (8), 1717-1722. DOI: 10.1016/j.jcms.2014.06.005.

5. Dmitriev, M.O., Gunas, I.V., Dzevulska, I.V., \& Zhulkevych, I.V. (2018). Determination of individual cephalometric characteristics of the occlusal plane in Ukrainian young men and young women with orthognatic bite. Biomedical and Biosocial Anthropology, 33, 5-11. DOI: 10.31393/bba33-2018-01

6. Baltrusaityte, A., Surna, A., Pileicikiene, G., Kubilius, R., Gleiznys, A., \& Baltrusaitis, M. (2013). Dynamical changes of occlusion and articulation during treatment of mandibular angle fractures. Stomatologija, 15 (1), 1219.

7. Zachariades, N., Papademetriou, I., \& Rallis, G. (1993). Complications associated with rigid internal fixation of facial bone fractures. J. Oral Maxillofac. Surg., 51 (3), 275-279. DOI: 10.1016/s0278-2391(10)80174-0.

8. Manson, P.N. (1986). Some thoughts on the classification and treatment of Le Fort fractures. Ann. Plastic Surg., 17 (5), 356-363. DOI:.

9. Kühnel, T.S., \& Reichert, T.E. (2015). Traumatologie des mittelgesichts. Laryngorhinootologie, 94 (Suppl. 1), S206-247. DOI: 10.1055/s-0034-1396873.

10. Maddux, S.D., \& Butaric, L.N. (2017). Zygomaticomaxillary morphology and maxillary sinus form and function: how spatial constraints influence pneumatization patterns among modern humans. Anat. Rec. (Hoboken), 300 (1), 209-225. DOI: 10.1002/ar.23447. 11. Shumynskyi, Ye.V., Kryshchuk, M.H., \& Kopchak, A.V. (2020). Biomekhanichnyi analiz metodiv vidnovlennia tsilisnosti vertykalnykh kontrforsiv verkhnoi shchelepy pry travmatychnykh perelomakh kistok serednoi zony oblychchia iz vykorystanniam indyvidualizovanykh skinchenno-elementnykh modelei [Biomechanical anal- ysis of methods for restoring the integrity of the maxilla vertical buttresses in midfacial bones fractures using individualised finite element models]. Visnyk stomatolohii - Stomatological Bulletin, 4 (113), $72-78$ [in Ukrainian].

12. McRae, M., \& Frodel, J. (2000). Midface fractures. Facial. Plast. Surg., 16 (2), 107-113. DOI: 10.1055/s-200012572.

13. AO CMF. Retrieved from: https://aocmf.aofoundation.org.

14. Roumeliotis G., Ahluwalia R., Jenkyn T., \& Yazdani A. (2015). The Le Fort system revisited: Trauma velocity predicts the path of Le Fort I fractures through the lateral buttress. Plast. Surg. (Oakv), 23 (1), 40-42. DOI: 10.4172/plastic-surgery.1000899.

15. De Feudis, F., De Benedittis, M., Antonicelli, V., Pittore, P., \& Cortelazzi, R. (2014). Decision-making algorithm in treatment of the atrophic mandible fractures. Chir, 35 (3-4), 94-100.

16. Kopchak, A., \& Shumynsky, Ie. (2020). Relation between paranasal sinuses and surrounding bone tissue. J. Educ. Health Sport, 10 (12), 22-31. DOI: 10.12775/ JEHS.2020.10.12.002.

17. Bagheri, S.C., Dierks, E.J., Kademani, D., Holmgren, E., Bell, R.B., Hommer, L., \& Potter, B.E. (2006). Application of a facial injury severity scale in craniomaxillofacial trauma. J. Oral Maxillofac. Surg., 64 (3), 408-414. DOI: 10.1016/j.joms.2005.11.013.

18. Bida, O.V. (2018). Dyferentsiiovani metody ortopedychnoho likuvannia ta fuknktsionalnoi reabilitatsii khvorykh z defektamy zubnykh riadiv, uskladnenykh zuboshchelepnymy deformatsiiamy [Differentiated methods of orthopedic treatment and functional rehabilitation of patients with dentition defects complicated by dental deformities]. Doctor's thesis. Ivano-Frankivsk : Ivano-Frankivskyi NMU [in Ukrainian].

19. Kanda, Y. (2013). Investigation of the freely available easy-to-use software 'EZR' for medical statistics. Bone Marrow Transplant., 48, 452-458.

20. Prafulla, T. (2016). Digital analysis of occlusion using T-Scan III in orthodontics. Journal of Indian Orthodontic Society, 50 (3), 196. DOI: 10.4103/0301-5742.186386.

21. Erkmen, E., Ataç, M.S., Yücel, E., \& Kurt, A. (2009). Comparison of biomechanical behaviour of maxilla following Le Fort I osteotomy with 2- versus 4-plate fixation using 3D-FEA: part 3: inferior and anterior repositioning surgery. Int. J. Oral Maxillofac. Surg., 38 (2), 173-179. DOI: 10.1016/j.ijom.2008.10.006.

22. Le Fort, R. (1901). Experimental study of fractures of the upper jaw Parts I and II. Rev. Chir. Paris, 23, 208.

23. Marciani, R.D. (1993). Management of midface fractures: fifty years later. J. Oral. Maxillofac. Surg., 51 (9), 960-968. DOI: 10.1016/s0278-2391(10)80035-7.

24. Wang, H., Chen, M.S., Fan, Y.B., Tang, W., \& Tian, W.D. (2007). Biomechanical evaluation of Le Fort I maxillary fracture plating techniques. J. Oral Maxillofac. Surg., 65 (6), 1109-1116. DOI: 10.1016/j.joms.2006.10.020.

25. Sutter, B.A. (2016). Incidence of headaches related to occlusion and bite force imbalance: a case study. Cranio, 34 (3), 195-207. DOI: 10.1179/2151090315Y.0000000006. 